\title{
Author Correction: Interplay between evanescence and disorder in deep subwavelength photonic structures
}

\author{
Hanan Herzig Sheinfux, Ido Kaminer, Azriel Z. Genack \& Mordechai Segev
}

Nature Communications 7:12927 doi:10.1038/ncomms12927 (2016); Published 6 Oct 2016; Updated 8 Feb 2018.

The original version of this Article contained an error in the caption to Fig. 2b, which incorrectly read 'Localization length as a function of $\theta$, the angle of incidence for $\lambda=1 \mu \mathrm{m}$ '. The correct version indicates that the calculation was performed for a wavelength of ' $\lambda=0.5 \mu \mathrm{m}$ ' and not ' $\lambda=1 \mu \mathrm{m}$ '. This has now been corrected in both the PDF and HTML versions of the article.

\footnotetext{
(c) (i) Open Access This article is licensed under a Creative Commons Attribution 4.0 International License, which permits use, sharing, adaptation, distribution and reproduction in any medium or format, as long as you give appropriate credit to the original author(s) and the source, provide a link to the Creative Commons license, and indicate if changes were made. The images or other third party material in this article are included in the article's Creative Commons license, unless indicated otherwise in a credit line to the material. If material is not included in the article's Creative Commons license and your intended use is not permitted by statutory regulation or exceeds the permitted use, you will need to obtain permission directly from the copyright holder. To view a copy of this license, visit http://creativecommons.org/licenses/by/4.0/
}

(C) The Author(s) 2018 